\title{
Growth Rates of Tree Height Six Years after Hurricane Damage at Four Localities in Eastern Nicaragua ${ }^{1}$
}

\author{
John Vandermeer ${ }^{2}$ \\ Department of Biology, University of Michigan, Ann Arbor, Michigan 48109, U.S.A.
}

Andrew Brenner

School of Natural Resources, University of Michigan, Ann Arbor, Michigan 48109, U.S.A.

and

Iñigo Granzow de la Cerda

Department of Biology, University of Michigan, Ann Arbor, Michigan 48109, U.S.A.

\begin{abstract}
Growth rates for 44 species of trees in a posthurricane forest in Nicaragua were measured. The pattern is consistent with the interpretation of succession as a two stage process: an initial building phase after the hurricane followed by a thinning phase. Localities that were damaged less from the hurricane are now entering the thinning phase of postdisturbance succession, while those subjected to the most severe damage appear to remain in the building phase.
\end{abstract}

Key words: disturbance; forest; hurricanes; tree growth.

Disturbance is recognized as an important eCOLOGICAl factor (Miller 1982, Sousa 1984, Pickett \& White 1985, Petraitis et al. 1989 Caswell \& Cohen 1991). In forests, windthrows are a major component of natural forest dynamics, whether in the form of a single felled tree creating a light gap (Brokaw 1987, Denslow 1987) or a large storm creating an extensive area of damage (Vandermeer et al. 1990, 1996; Brokaw \& Walker 1991, Yih et al. 1991). Understanding the details of postdisturbance succession remains an important research goal of forest ecology. Here we present data on the rate of growth in tree height of the trees in a lower canopy of a regenerating rain forest, following the catastrophic damage of a hurricane six years ago.

Hurricane Joan struck the eastern seaboard of Nicaragua in October 1988, causing extensive damage to the lowland rain forests (Boucher 1989,Vandermeer et al. 1990). In the six years following the hurricane, we have witnessed the successional processes at four localities. The forest initially exhibited major physical damage with the majority of trees either coppiced, truncated or felled (Yih et al. 1991) with complete defoliation of all trees. How-

1 Received 2 July 1996; second revision accepted 6 June 1997.

2 Corresponding Author: John Vandermeer, Department of Biology, University of Michigan, Ann Arbor, Michigan 48109; e-mail jvander@umich.edu ever, soon there was a large amount of resprouting in almost all damaged trees (Vandermeer et al. 1990, Yih et al. 1991), followed by a large delayed mortality the following year (Boucher et al. 1996). The trees that remained standing resprouted high on the trunk and formed a diffuse canopy, 15-20 $\mathrm{m}$ high. The resprouts, surviving saplings and seedlings, and the newly arrived saplings and seedlings have grown to form a low-statured canopy that is currently very dense. The process of forming this low-lying canopy is referred to as the "building phase," while the subsequent phase of intense competition is the "thinning phase" (Vandermeer et al. 1996).

We now observe a diffuse upper canopy ( $c a$ 15-20 m high) and a dense lower canopy (ca $9 \mathrm{~m}$ high; Vandermeer et al. 1996). It is in this lower canopy that we expect the process of competition to be operative, eventually leading to the elimination of many of the currently competing individuals.

Tree growth in the lower dense canopy, especially extension in height, is expected to follow certain patterns, depending upon the rate and degree of succession. We expect that the average growth rates will decline as succession proceeds. This expectation can be illustrated graphically (Fig. 1 ), in which species are divided into pioneer, heliophyte, and primary forest species, and the postdamage time sequence is divided into building 


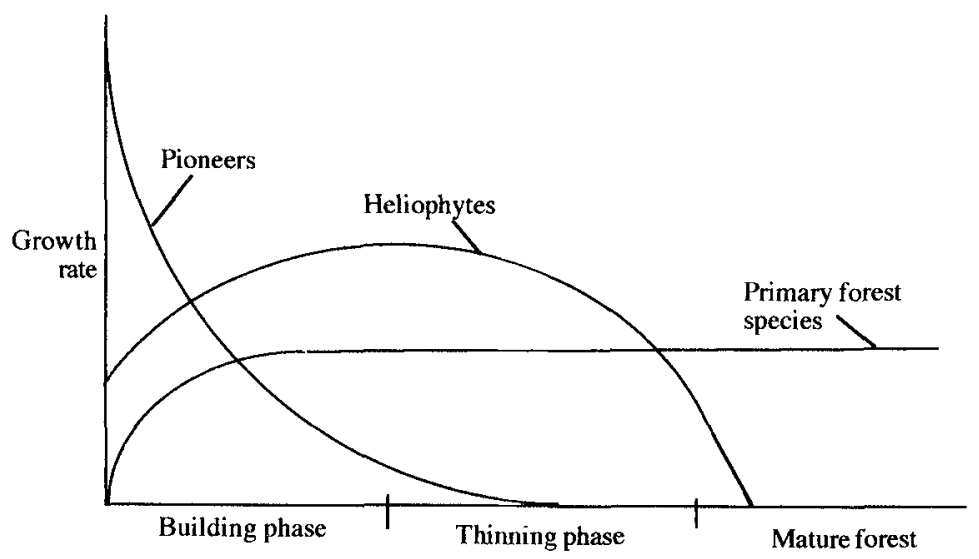

FIGURE 1. Diagrammatic representation of expected growth rates along the successional gradient for three guilds of rain forest trees.

phase, thinning phase and mature forest. Furthermore, as the successional process proceeds from building phase to thinning phase, we expect the variability of growth rates (from individual to individual in a given species) to change from low to high, due to the shading of individuals in the lower canopy by faster-growing individuals.

Our hypothesis is that in the thinning phase, all species will have low growth rates, while in the building phase, the pioneers will be growing fastest (with the heliophytes and primary forest species having depressed growth rates) because of competition from vines and other pioneer vegetation.

\section{METHODS}

The study was conducted in the region surrounding Bluefields, on the southern Caribbean coast of Nicaragua (the core area damaged by Hurricane Joan). Data from four sites located within the damaged area (Fig. 2) are reported. Background information on the choice and details of the sites are given in Vandermeer et al. (1996). Note that Bodega is almost exactly in the center of the hurricane damage area while Fonseca is near the edge of that damage. Loma de Mico is intermediate, but closer to the edge than the center. La Unión is a unique site in that the permanent plot there is directly to the west of a large hill, thus partly protected from the major winds of the hurricane. The appearance of this forest supports the expectation that it was the least damaged of all four plots. We take the relative position of each of the plots as a rough estimate of the position we expect to find the forest on the time axis of Figure 1. At one extreme, we expect that Bodega will still be in the building phase since it sustained considerably more damage than the others while we expect Fonseca and $\mathrm{La}$ Unión to be at least approaching the thinning phase, due to their having experienced less damage. All sites are on level ground and the soils are ultisols (judging from soil maps and general appearance) with apparently similar drainages. Soil analysis (Vandermeer, pers. obs.) at Bodega and Fonseca indicated no significant differences in major nutrients, soil organic matter, or $\mathrm{pH}$. There is no reason to expect significant site differences in terms of physical factors.

Beginning in 1994, tree heights were measured by means of a telescoping pole. The highest leaf on the tallest branch was taken to be the height. Because of logistic difficulties, not all trees were measured in 1994 and the remaining individuals were measured in 1995. In 1996, the heights were measured for all individuals at all four sites. Growth rates $(\mathrm{m} / \mathrm{yr})$ were calculated as either the difference between the heights in 1996 and 1995, or the difference between the heights in 1996 and 1994 divided by two. Growth rates were analyzed with an analysis of variance, after first using Bartlett's test for homogeneity of group variances. Tukey's honestly significant difference (HSD) tests were used for pairwise comparisons.

Height measurements are difficult for a variety of reasons, making the accuracy of the measurements questionable. First, it is difficult to see the top of the tree under current canopy conditions, with intertangled branches from many trees obstructing vision from almost every angle. Second, judging which branch actually ascends to the high- 


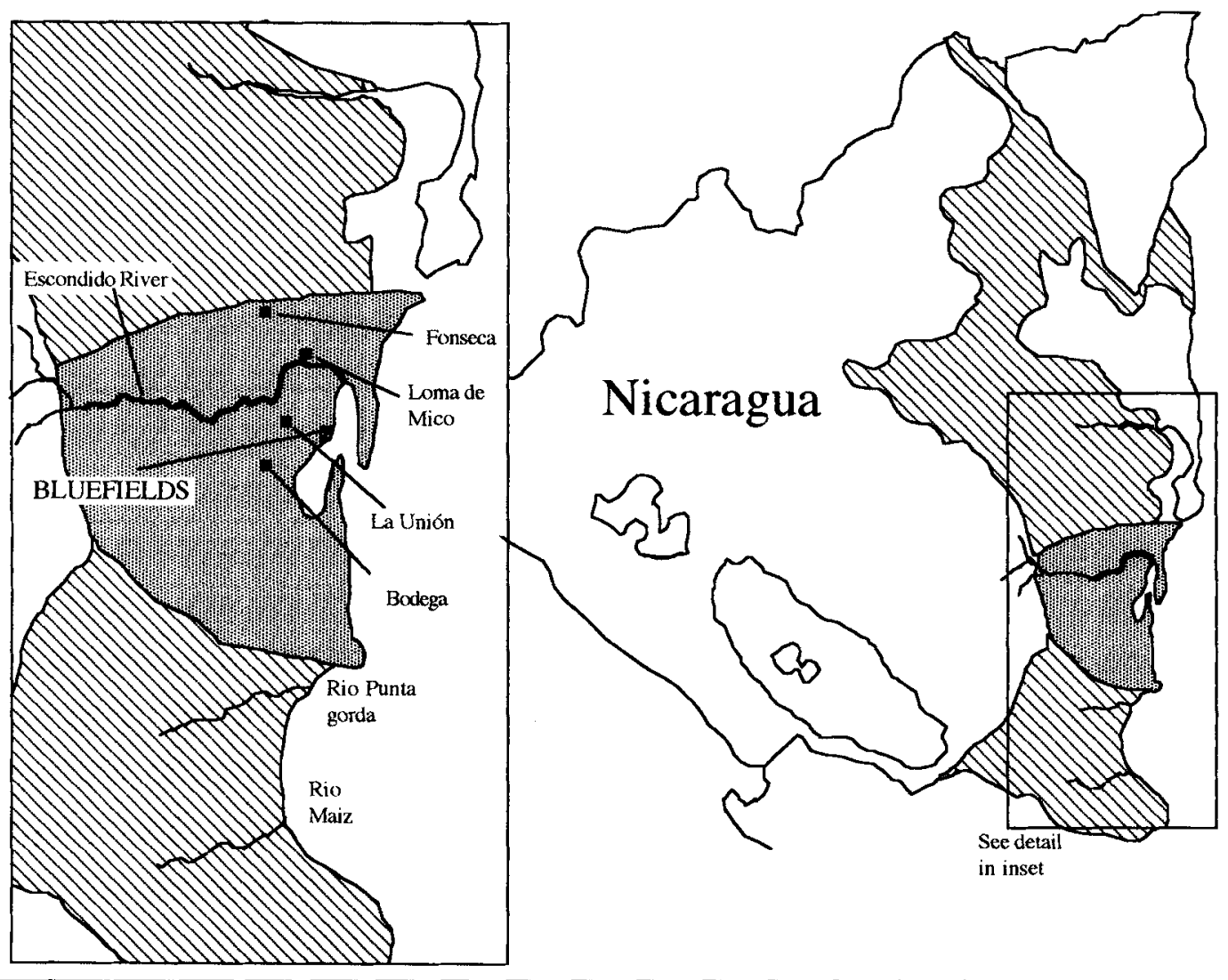

FIGURE 2. Map of Nicaragua showing area of damage and position of the four sites in this study. Diagonal hatching indicates the approximate position of original lowland tropical rain forest, and dark shading indicates approximate extent of hurricane damage.

est point may be influenced by the particular position the observer takes in the forest; and thus the branch measured may change from one year to the next. However, these biases are not likely to be systematic. We thus have confidence in average figures but do not put much emphasis on the growth of individual trees in this paper.

TABLE 1. Basic statistics for rate of growth in height at the four sites. Different lower case letters signify statistically significant differences at the 95 percent level.

\begin{tabular}{lcccc}
\hline & $\bar{x}$ & SD & $N$ & $C V$ \\
\hline Bodega & $0.858 \mathrm{a}$ & 0.990 & 934 & 115 \\
Loma de Mico & $0.643 \mathrm{~b}$ & 0.663 & 575 & 151 \\
Fonseca & $0.486 \mathrm{c}$ & 1.324 & 847 & 272 \\
La Union & $0.332 \mathrm{c}$ & 0.902 & 409 & 271 \\
\hline
\end{tabular}

\section{RESULTS}

All growth rates were pooled at each of the four sites (Table 1). As expected, the average growth rate for Bodega was largest, since the most severe hurricane damage had been at this site and growth into the lower canopy was still proceeding. The other three sites had smaller average growth rates since damage had been less severe. An analysis of variance indicated that there were significant differences among the average growth rates at the different sites $(F=31.3, P<0.001$; Bartlett's test for homogeneity of group variances yielded a chisquare of $311.4, P<0.001$ ). Pairwise comparisons indicated strong differences between Bodega and all other three sites and weaker differences among Loma de Mico, Fonseca, and La Unión (Table 1). Variability, as measured by the coefficient of variation $(C V)$, was as expected with the lowest vari- 
TABLE 2. Summary of height growth rates ( $m / y r)$ at all four sites.

\begin{tabular}{|c|c|c|c|c|}
\hline Scientific name & Bodega & Loma de Mico & Fonseca & La Unión \\
\hline Acidoton nicaraguense & 0.3093 & & & \\
\hline Amaioua corymbosa & & 0.3271 & & \\
\hline Ardisia sp. & -0.0127 & & 0.48 & \\
\hline Astrocaryum alatum & & 0.3088 & & \\
\hline Byrsonima crassifolia & 0.9725 & & 1.005 & \\
\hline Casearia arborea & 1.181 & & & 0.5121 \\
\hline Casearia sylvestris & & & & 0.2348 \\
\hline Cecropia obtusifolia & & & 0.5272 & 0.4528 \\
\hline Cordia bicolor & 1.153 & & & \\
\hline Croton schiedeanus & & & -0.4582 & \\
\hline Croton smithianus & 1.2356 & 0.8571 & 0.5593 & \\
\hline Cupania glabra & 0.808 & 0.6743 & 0.7051 & \\
\hline Dendropanax arboreus & 0.748 & & -0.0954 & 0.2274 \\
\hline Galiped granulosa & & & 0.8233 & \\
\hline Goethalsia meiantha & & & 0.3974 & \\
\hline Guatteria diospyroides & & & & 0.2455 \\
\hline Guatteria recurvisepala & 1.349 & 0.9352 & -0.0656 & \\
\hline Guettarda combsii & & 0.6024 & & \\
\hline Guettarda deamii & & 0.8262 & 1.0942 & \\
\hline Henrietea seemannii & 0.931 & & & \\
\hline Hirtella americana & 0.62 & & 0.4028 & \\
\hline Hirtella guatemalensis & & 0.4854 & & \\
\hline Hyeronima alchorneoides & & & & 0.3822 \\
\hline Inga cocleensis & 0.933 & 0.8871 & 0.9678 & \\
\hline Inga thibaudiana & 1.148 & & & \\
\hline Isertia haenkeana & 0.513 & 0.0947 & 0.44 & \\
\hline Lacistema aggregatum & 0.718 & & & 0.6284 \\
\hline Mabea occidentalis & 1.089 & 0.6359 & & \\
\hline Manilkara zapota & & & 0.8618 & \\
\hline Miconia prasina & 1.049 & 0.7471 & 0.6986 & \\
\hline Myrcia sp. & 0.97 & & & \\
\hline Piper auritum & & & & 0.053 \\
\hline Protium schippii & 0.956 & & & \\
\hline Pseudolmedia spuria & 0.789 & & 0.1221 & \\
\hline Qualea paraensis & 0.809 & & & \\
\hline Rinorea squamata & 0.132 & & -0.0707 & \\
\hline Simarouba amara & 1.533 & & & \\
\hline Spachea correae & & 0.721 & & \\
\hline Terminalia amazonia & 2.177 & & & \\
\hline Tetragastris panamensis & & 0.477 & 0.3538 & \\
\hline Unonopsis pittieri & 0.723 & & & \\
\hline Virola koschnyi & & & & 0.5608 \\
\hline Vismia macrophylla & 1.44 & & & \\
\hline Vochysia ferruginea & 1.281 & 1.154 & 0.5586 & \\
\hline $\bar{x}$ & 0.9465 & 0.6489 & 0.4653 & 0.3663 \\
\hline
\end{tabular}

ability at Bodega and the highest at Fonseca and La Union (Table 1).

For 44 species, a minimum of 9 individuals occurred at least once at each site, enabling the calculation of growth rates for these individual species (Table 2). Values ranged from $2.2 \mathrm{~m} / \mathrm{yr}$ (Terminalia amazonia at Bodega) to negative $0.5 \mathrm{~m} / \mathrm{yr}$ (Croton schiedeanus at Fonseca). This general pattern reflected the same as for the pooled growth rates, with the means of these 44 species ordered in the same way (i.e., Bodega highest, followed by
Loma de Mico, Fonseca, and La Unión). While no individual species occurred abundantly enough at all four localities to have growth rates computed, several species occurred at three of the localities. For example, Croton smithianus, a classic pioneer species (Vandermeer et al. 1997), had a pattern of a fast growth rate at Bodega $(1.2 \mathrm{~m} / \mathrm{yr})$, a slower rate at Loma de Mico $(0.9 \mathrm{~m} / \mathrm{yr})$, and a yet slower rate at Fonseca $(0.6 \mathrm{~m} / \mathrm{yr})$. Guatteria recurvisepala and Miconia prasina, both heliophytes (Vandermeer et al. 1997), showed similar patterns, with $G$. re- 


\section{Pioneers/heliophytes}
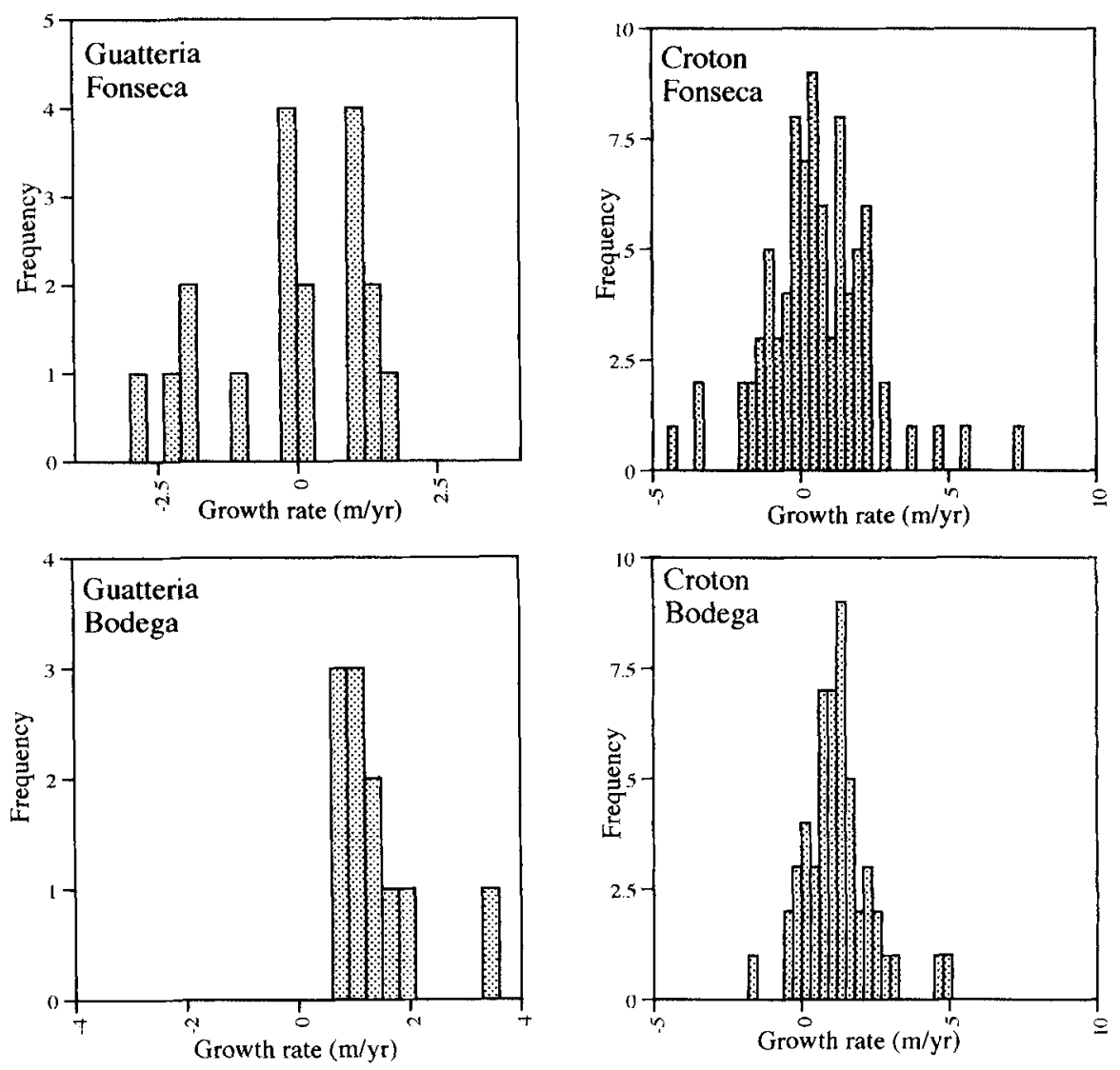

FIGURE 3. Histograms of growth rates for four illustrative species at two of the sites.

curvisepala having a negative growth rate in Fonseca. On the other hand, two primary forest species (i.e., Cupania glabra, Inga cocleensis) did not show that general pattern, while Vochysia ferrugined, another primary forest species, had high levels of growth in all three sites where it occurred abundantly.

A more detailed comparison was made between the two geographically extreme sites, Bodega and Fonseca. Twelve species were common enough in both sites to be evaluated: 4 pioneers/heliophytes (Croton smithianus, Guatteria recurvisepala, Isertia haenkeana, Miconia prasina) and 8 primary forest species (Vochysia ferruginea, Cupania glabra, Inga cocleensis, Hirtella americana, Dendropanax arboreus, Byrsonima crassifolia, Pseudolmedia spuria, and Rinorea squamata). Mean growth rates were calculated for each of these 12 species at the two sites.
A paired $t$-test was performed on each and the $C V$ was calculated (Table 3). As expected, 3 of 4 pioneers/heliophytes showed a difference between the two sites in their growth rates, still growing quite rapidly in Bodega but with significantly reduced growth rates in the more successionally advanced Fonseca. In contrast, the primary forest species ( $\mathrm{T}_{2}-$ ble 3) did not show a difference in growth rates between the two sites, again as expected.

In 11 of the 12 species in this comparison ( $\mathrm{Ta}$ ble 3), the $C V$ was greater in Fonseca than in Bodega. The one exception was Byrsonima crassifolia, which had almost the same $C V$ for both sites. A paired $t$-test showed the $C V$ s to be significant between Fonseca and Bodega; applied directly to $C V s$ and after logrithmic transformation, Wilcoxon signed rank test gave a significance of 0.002). This was as expected from the basic theory of plant 


\section{Primary forest species}
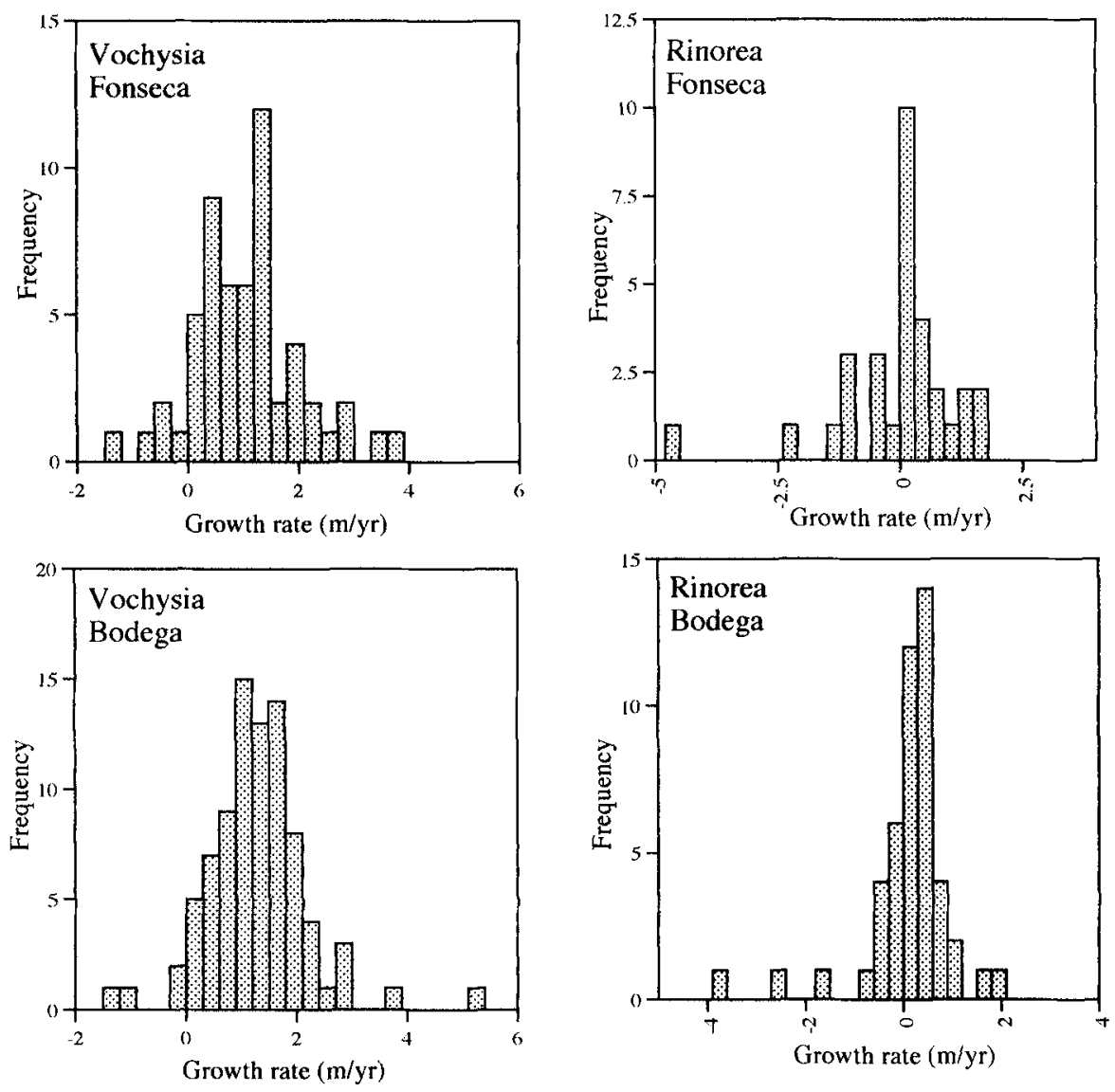

Figure 3. Continued.

competition, according to the hypothesis that Fonseca is further along in the successional process such that some individuals are now being suppressed while others are growing well. In Figure 3 we illustrate typical distributions for both the pioneer/heliophyte category and the primary forest category. In both cases it is apparent that the variability at Fonseca is greater than the variability at Bodega with different means for the pioneer/heliopytes but not for the primary forest species.

\section{DISCUSSION}

What one expects to find in the growth rate of tree heights depends on where the forest is located on the time axis of Figure 1. If the successional process is very slow, we might expect all pioneers to grow very rapidly while the primary forest species remain growth limited by these pioneers and other nonarborescent vegetation such as vines. Our expectation was that Bodega would be nearer to the origin of the time axis (Fig. 1) while the other sites would be farther to the right of that axis. This is the pattern we find. Comparing growth rates of pioneers/ heliophytes from Bodega to those from Fonseca, we find a clear pattern of reduced growth rate at the latter site. The only exception to this pattern is Isertia haenkeana, a small subcanopy tree that we suspect has reached its maximum growth capacity at all sites.

This result is consistent with our interpretation of the successional process (Vandermeer et al. 1996) as a two stage process involving an initial building phase after the hurricane followed by a 
TABLE 3. Basic statistics for the species found commonly at both Fonseca and Bodega (t and $\mathrm{p}$ refer to growth rate).

\begin{tabular}{|c|c|c|c|c|c|c|c|}
\hline & $\begin{array}{l}\text { Mean } \\
\text { growth } \\
\text { rate } \\
\text { Fon }\end{array}$ & $\begin{array}{l}\text { Mean } \\
\text { growth } \\
\text { rate } \\
\text { Bod }\end{array}$ & $\begin{array}{l}C V \\
\text { Fon }\end{array}$ & $\begin{array}{c}C V \\
\text { Bod }\end{array}$ & $\mathrm{df}$ & $t$ & $P$ \\
\hline \multicolumn{8}{|l|}{ Pionecrs/heliophytes } \\
\hline $\begin{array}{l}\text { Croton smithianus } \\
\text { Guatteria recurvisepala } \\
\text { Isertia haenkeana } \\
\text { Miconia prasina }\end{array}$ & $\begin{array}{l}0.559 \\
-0.07 \\
0.440 \\
0.698\end{array}$ & $\begin{array}{l}1.236 \\
1.349 \\
0.518 \\
1.049\end{array}$ & $\begin{array}{r}316 \\
2030 \\
256 \\
127\end{array}$ & $\begin{array}{r}94 \\
60 \\
116 \\
49\end{array}$ & $\begin{array}{r}134 \\
27 \\
61 \\
108\end{array}$ & $\begin{array}{l}2.44 \\
3.168 \\
0.314 \\
2.574\end{array}$ & $\begin{array}{l}0.016 \\
0.004 \\
0.754 \\
0.011\end{array}$ \\
\hline \multicolumn{8}{|l|}{ Primary forest species } \\
\hline $\begin{array}{l}\text { Vochysia ferruginea } \\
\text { Cupania glabra } \\
\text { Inga cocleensis } \\
\text { Hirtella americana } \\
\text { Dendropanax arboreus } \\
\text { Byrsonima crassifolia } \\
\text { Pseudolmedia spuria } \\
\text { Rinorea squamata }\end{array}$ & $\begin{array}{l}1.057 \\
0.705 \\
0.968 \\
0.403 \\
-0.10 \\
0.943 \\
0.122 \\
-0.07\end{array}$ & $\begin{array}{l}1.281 \\
0.823 \\
0.933 \\
0.620 \\
0.748 \\
1.048 \\
0.789 \\
0.132\end{array}$ & $\begin{array}{r}90 \\
181 \\
126 \\
273 \\
900 \\
50 \\
1179 \\
1770\end{array}$ & $\begin{array}{r}70 \\
92 \\
69 \\
123 \\
114 \\
70 \\
96 \\
686\end{array}$ & $\begin{array}{r}139 \\
102 \\
21 \\
36 \\
34 \\
32 \\
38 \\
77\end{array}$ & $\begin{array}{l}1.417 \\
0.578 \\
0.090 \\
0.711 \\
1.912 \\
0.444 \\
1.861 \\
-0.84\end{array}$ & $\begin{array}{l}0.159 \\
0.564 \\
0.929 \\
0.482 \\
0.064 \\
0.660 \\
0.070 \\
0.403\end{array}$ \\
\hline
\end{tabular}

thinning phase. During the building phase, a low canopy is formed from resprouted saplings and previously existing seedlings. This low canopy is currently very dense and is where intense crown competition among the individual trees that form it occurs. From this intense competition we expect a thinning process to follow (Vandermeer et al. 1996). The less damaged sites are more likely to be entering this thinning phase and those trees do show slower average growth rates.

Further evidence that we have entered the thinning phase at Loma de Mico, Fonseca and La Unión comes from the distribution of growth rates at all four sites. The $C V$ at Bodega is 1.15 whereas at the other three sites it is $1.51,2.72$, and 2.72, as we move to Loma de Mico, Fonseca, and La Unión. The high $C V$ for La Unión is probably due to that plot being protected from the high winds by the large hill to its east, as noted earlier. Furthermore, by comparing a variety of species from Bodega to those same species from Fonseca, we find a significant trend toward increased $C V$ s in almost all species.

Taking the evidence of average growth rates along with that from differences in $C V$ s from site to site, we conclude that the forests that were damaged less from the hurricane are now entering the thinning phase of postdisturbance succession, while those subjected to the most severe damage appear to remain in the building phase.

\section{ACKNOWLEDGMENTS}

This work was supported by NSF Grants BSR 8917688 and DEB-9524061. We wish to thank the Center for Information and Documentation of the Atlantic Coast, in Bluefields, Nicaragua, for logistic support.

\section{LITERATURE CITED}

Boucher, D., J. H. Vandermelr, M. A. Mallona, N. Zamora, I. Pfrfecto and I. Granzow de la Cerda. 1996. Mortalidad masiva y retardada de arboles despues del huracan Juana. Wani 19: 38-42.

Ввоклш, N. V. L. 1987. Gap-phase regeneration of three pioneer tree species in a tropical forest. J. Ecol. 75: 9-19.

- AND L. R. WAIKFR, 1991. Summary of the effects of Caribbean hurricanes on vegetation. Biotropica 23: $442-447$.

CAsweil., H., AND J. E. Collen. 1991. Communities in patchy environments: a model of disturbance, competition, and heterogeniety. In J. Kolasa (Ed.). Ecological heterogeneity, pp. 97-122. Springer-Verlag, New York, New York.

Densiow, J. S. 1987. Tropical rainforest gaps and tree species diversity. Annu. Rev. Ecol. Syst. 18: $431-451$.

Minler, T. E. 1982. Community diversity and interactions between the size and frequency of disturbance. Am. Nat. 120: 533-536.

Peitratis, P. S., R. A. Latham, and R. A. Nirsminaum. 1989. The maintenance of species diversity by disturbance. Q. Rev. Biol. 64: 393-418. 
Picket', S. T. A., and P. S. White (Eds.). 1985. Natural disturbance and patch dynamics. Academic Press, New York, New York, 472 pp.

Sousa, W. P. 1984. The role of disturbance in natural communities. Annu. Rev. Ecol. Syst. 1984. 15: 353-391.

Vandermeer, J. H., I. Granzow de la Cerda, and D. Boucher. 1997. Contrasting growth rate patterns in eighteen tree species from a posthurricane forest in Nicaragua. Biotropica 29: 151-161.

- D. Boucher, I. Perfecto, and I. Granzow de la Cerda. 1996. A theory of disturbance and species diversity: evidence from Nicaragua after Hurricane Joan. Biotropica 28: 600-613.

- N. Zamora, K. Yih, AND D. Boucher. 1990. Regeneración inicial en una selva tropical en la costa caribeña de Nicaragua después del huracan Juana. Revista Biología Tropical (Costa Rica) 38: 347-359.

Yih, K., D. H. Boucher, N. Zamora, nND J. H. Vandermeer. 1991, Recovery of the rain forest of southeastern Nicaragua after destruction by Hurricane Joan. Biotropica 23: 106-113. 